\title{
Peningkatan kompetensi kewirausahaan melalui program pengembangan produk unggulan daerah kain khas daerah Palembang
}

\author{
Bainil Yulina $^{1 *}$, Evada Dewata ${ }^{1}$, Anggeraini Oktarida ${ }^{1}$, Pridson Mandiangan ${ }^{2}$, Nurul Aryanti ${ }^{3}$, \\ \& Welly Ardiansyah ${ }^{3}$
}

${ }^{1}$ Jurusan Akuntansi, Politeknik Negeri Sriwijaya, Indonesia

${ }^{2}$ Jurusan Administrasi Bisnis, Politeknik Negeri Sriwijaya, Indonesia.

${ }^{3}$ Jurusan Bahasa Inggris, Politeknik Negeri Sriwijaya, Indonesia

*byulina@gmail.com

\begin{abstract}
Abstrak. Kompetensi wirausaha merupakan faktor mendasar yang dimiliki seseorang yang mempunyai kemampuan lebih, yang membuatnya berbeda dengan seorang yang mempunyai kemampuan rata-rata. Kompetensi kewirausahaan adalah karakteristik individu yang termasuk sikap dan kebiasaan, dimana wirausaha dapat mencapai dan mempertahankan kesuksesan bisnisnya. KUBe Griya Kain Tuan Kentang beralamat di kawasan Tuan Kentang 4 Ulu Palembang menaungi 24 pengrajin kain khas Palembang. Kain tenun dan batik corak khusus yang unik.ini semakin populer dan terkenal dipakai sebagai bahan desain mode pakaian, aksesoris kalung dan tas. Terlebih Pemerintah daerah Palembang menjadikan kain tenun tersebut sebagai pakaian wajib untuk seragam dinas di hari jumat dan hari hari khusus. Kondisi ini memberikan peluang besar bagi KUBe untuk meningkatkan kualitas produknya sampai ke mancanegara Permasalahan pada KUBe Griya Kain Tuan Kentang mempunyai sumber daya manusia dengan kompetensi terbatas, belum mampu berbahasa Inggris secara aktif, pengetahuan pembukuan dan penyusunan laporan keuangan serta pengetahuan dan penerapan pajak pada aktivitas bisnis kain tenun Palembang. Program Pengembangan Produk Unggulan Daerah Kain Tenun khas Palembang adalah kegiatan penerapan IPTEK dari Politeknik Negeri Sriwijaya yang didanai melalui Dirjen Dikti sebagai upaya pengembangan budaya aset daerah Palembang berupa kain tenun tajung, blongsong dan jupri. Kegiatan ini bertujuan untuk memacu dan mengembangkan kain tenun unggulan khas daerah Palembang sebagai usaha peningkatan kualitas, kuantitas produk, distribusi dan pemasaran. Untuk meningkatkan kompetensi Kewirausahaan diadakan pelatihan berbahasa Inggris praktis, Penyusunan Laporan Keuangan, Perhitungan dan Penetapan Harga jual, Perhitungan dan Penetapan pajak penjualan bagi pengurus Kube dan Pemilik UMKM. Metode pelaksanaan dilakukan dengan mensosialisasikan kegiatan, mengadakan pelatihan yang terjadwal sesuai dengan kesepakatan dan pendampingan kegiatan, untuk melihat keberhasilan kegiatan diadakan evaluasi dengan cara monitoring dan penyebaran pertanyaan. Luaran yang dihasilkan berupa peningkatan pengetahuan bagi pengurus dan pengelola, dengan kata lain Kompetensi Kewirausahaan Sumber Daya Manusia Kube Griya Tuan Kentang meningkat $45 \%$.
\end{abstract}

Kata kunci: kompetensi kewirausahaan, program pengembangan produk unggulan daerah, kain khas daerah Palembang

Abstract. Entrepreneurial competence is a fundamental factor possessed by someone who has more abilities, which makes him different from someone who has average abilities. Entrepreneurial competence is an individual characteristic which includes attitudes and habits, where entrepreneurs can achieve and maintain business success. KUBE Griya Kain Tuan Kentang is located in the Tuan Kentang 4 area of Ulu Palembang and houses 25 Palembang-style cloth craftsmen. Weaving fabrics and batik with a unique special pattern. These are increasingly popular and are known to be used as materials for fashion designs for clothing, accessories for necklaces and bags. Moreover, the Palembang local government made the woven cloth a mandatory garment for official uniforms on Fridays and special days. This condition provides a great opportunity for KUBE to improve the quality of its production to foreign countries The problem with Kube Griya Kain Tuan Kentang has human resources with limited competence, is not able to speak English actively, knowledge of bookkeeping and preparation of financial reports as well as knowledge and application of taxes on business activities Palembang woven fabrics. The Regional Superior Product Development Program for Palembang's unique woven fabrics is an activity of implementing science and technology from the Sriwijaya State Polytechnic funded through the Director General of Higher Education as an effort to develop the cultural assets of the Palembang area in the form of tajung, blongsong and jupri woven fabrics. This activity aims to spur and develop superior woven fabrics typical of the Palembang region as an effort to improve quality, product quantity, distribution and marketing. To improve entrepreneurship competence, practical English language training was held, Financial Report Preparation, Selling Price Calculation and Determination, Calculation and Determination of Sales Tax for Kube Administrators and MSME Owners The method of implementation is carried out by disseminating activities, holding scheduled training in accordance with the agreement and mentoring activities, to see the success of the activity an 
evaluation is held by means of monitoring and distributing questions. The resulting output is in the form of increased knowledge for administrators and managers, in other words the Entrepreneurship Competence of Human Resources of Kube Griya Tuan Kentang has increased by $45 \%$.

Keywords: entrepreneurship competence, regional superior product

To cite this article: Yulina, B., E. Dewata., E. Oktarida., P. Mandiangan., N. Aryanti., \& W. Ardiansyah. 2020.

Peningkatan kompetensi kewirausahaan melalui program pengembangan produk unggulan daerah kain khas daerah Palembang. Unri Conference Series: Community Engagement 2: 310-316. https://doi.org/10.31258/unricsce.2.310$\underline{316}$

(C) 2020 Authors

Peer-review under responsibility of the organizing committee of Seminar Nasional Pemberdayaan Masyarakat 2020

\section{PENDAHULUAN}

Pelaku usaha yang giat melakukan inovasi dan kreativitas adalah para wirausahawan yang bergerak di sektor Usaha Mikro Kecil Menengah (UMKM). Mereka memiliki peran penting dalam mendorong pertumbuhan Ekonomi di Indonesia sehingga menjadi salah satu prioritas dalam pembangunan ekonomi nasional. Hal ini selain karena usaha tersebut merupakan tulang punggung sistem ekonomi kerakyatan yang tidak hanya ditujukan untuk mengurangi masalah kesenjangan antar golongan, pendapatan dan antar pelaku usaha, pengentasan kemiskinan dan penyerapan tenaga kerja. Lebih dari itu, pengembangannya mampu memperluas bisnis ekonomi dan dapat memberikan kontribusi dalam mempercepat perubahan struktural, yaitu meningkatnya perekonomian daerah dan ketahanan ekonomi nasional.

Kinerja usaha mikro kecil di Indonesia membutuhkan kerja keras karena masih sangat terbelakang dalam menuangkan ide kreatif produknya untuk mampu bersaing dan tidak berkembang atau bahkan gulung tikar. Hal ini disebabkan karena rendahnya kompetensi yang dimiliki. Relevan dengan hal itu Dipta (2012) mengemukakan bahwa rendahnya kualitas Sumber Daya Manusia (SDM) atau dengan kata lain rendahnya kompetensi Kewirausahaan. Hal ini juga ditunjukkan dengan masih rendahnya pengembangan dan penguasaan ilmu pelaku UMKM di bidang manajemen, organisasi, teknologi, pemasaran dan kompetensi lainnya yang diperlukan dalam mengelola usaha.

Kawasan Tuan Kentang adalah kawasan daerah pengrajin kain tenun dan jumputan khas Palembang. Dengan jumlah pengrajin lebih dari 100 Tuan kentang menjadi daerah yang sangat memiliki potensi untuk dijadikan destinasi wisata Palembang. Untuk mewujudkan itu Pemerintah Palembang melalui dinas perindustrian dan Bank Indonesia membangun gedung yang akan digunakan sebagai pusat aktivitas pengrajin tenun dan jumputan yang ada di Tuan kentang. Untuk memudahkan meningkatkan kualitas produk, menjual hasil produk dan mensejahterakan Pengrajin Tenun dan Jumputan membentuk Kelompok Usaha Bersama (KUBe) Griya Tuan Kentang yang difasilitasi BI. Tercatat pada tanggal 25 Januari 2017 KUBe Griya Kain Tuan Kentang berdiri dengan membina 25 anggota yang merupakan pengrajin kain tenun dan jumput, memfasilitasi anggota untuk menjualkan produk di galeri dengan kualitas produk yang terbaik.KUBe memiliki galeri yang menjual produk anggota.produk yang dijual diantaranya Tenun tajung, Blongsong dan Jupri memiliki banyak variasi produk diantaranya sarung tajung, bahan tajung, blongket, blongket tabur emas, dan kombinasi jumputan dan tenun. 


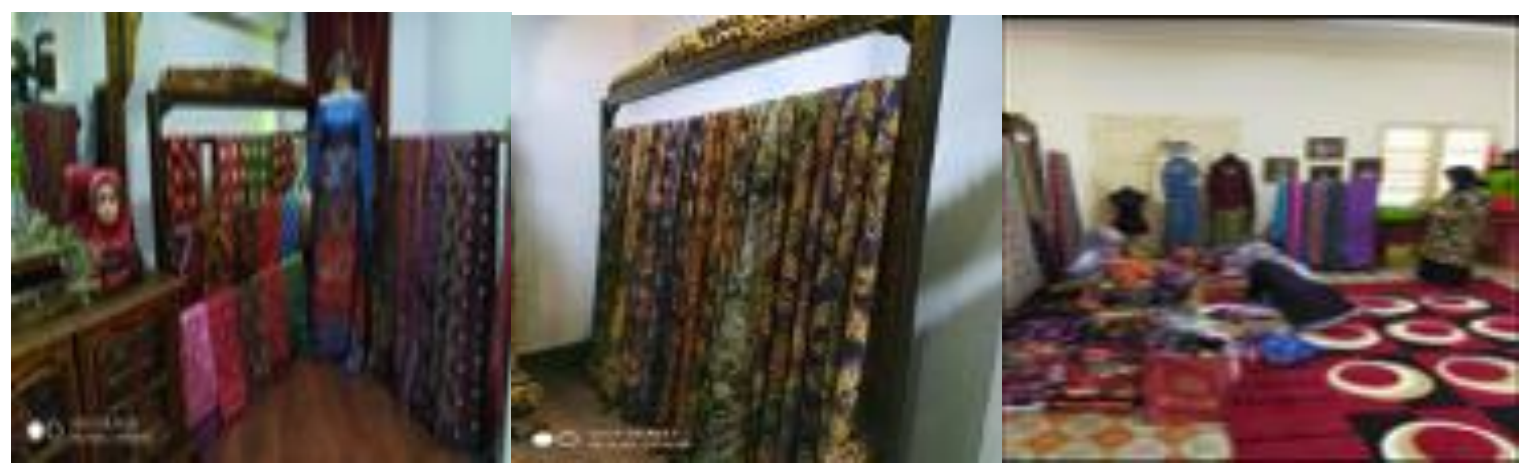

Gambar 1. Produk Kain Tenun Khas Daerah Palembang

Berdasarkan data Dinas Perindustrian, Perdagangan dan Koperasi Kota Palembang, sebanyak 9747 usaha yang bergerak dalam bidang perdagangan, usaha mikro 467 Unit usaha kecil 7484 Unit usaha kecil dan 1794 Unit usaha menengah tetapi pertumbuhan unit usaha ini sangat lambat perkembangannya, masih terbatasnya pembinaan dan fasilitas yang diberikan Pemerintah dan instansi lainnya (Disperindagkop, 2013).

Salah satu sektor yang mendominasi kegiatan usaha kecil di Palembang adalah sektor kerajinan, khususnya songket dan tenun. Terdapat banyak pengrajin songket dan tenun yang tersebar di wilayah kota Palembang. Harga yang ditawarkan pun bermacam-macam, mulai dari yang sangat terjangkau sekitar lima puluh ribu sampai dengan yang paling mahal mencapai jutaan rupiah tergantung dari tingkat kesulitan pembuatan kain. Sesuai survei yang telah dilakukan kepada UMKM kain tenun di Kawasan Tuan kentang, Sebanyak 90 Unit usaha yang bergerak dalam bidang penjualan kain tenun Palembang, yang tercatat dalam keanggotaan KUBe sebanyak 24 Unit usaha. Pemilik usaha merangkap juga sebagai pengrajin. Berdasarkan data dari Ketua KUBe Griya Tuan Kentang, pemilik usaha ini bervariasi dari kelompok usia 25 tahun sampai dengan 60 tahun, dari latar belakang pendidikan sekolah dasar dan sarjana, juga omzet penjualan mulai dari delapan puluh juta rupiah sampai satu milyar lima ratus juta rupiah perbulannya. Adanya persaingan yang sangat ketat dalam merebut pasar. Hal ini dibuktikan dengan adanya persaingan dari segi harga, inovasi produk, maupun pelayanan yang diberikan untuk menarik konsumen. Saat ini, banyak dari UMKM yang lebih mementingkan harga murah tanpa memperhitungkan kualitas dari produk atau jasa itu sendiri, sehingga UMKM hanya mendapatkan keuntungan jangka pendek. Inovasi yang beragam harusnya selalu dilakukan oleh UMKM untuk kemajuan usaha mereka. UMKM yang tidak dapat menyesuaikan diri dengan pasar melalui harga dan inovasi, lambat laun akan mengalami penurunan omset. Ketatnya persaingan dalam memperoleh omset tersebut akan menjadi hal serius bagi UMKM. Apabila penurunan omset terjadi secara terus menerus maka UMKM mau tidak mau harus menambah modal untuk memperlancar operasional usaha tersebut. Tetapi banyak dari UMKM yang tidak memiliki modal yang cukup (modal minim). Pada saat UMKM tidak memiliki modal, UMKM tidak dapat merebut pasar atau memiliki daya saing yang rendah. Dengan kata lain, minimnya modal menjadi penyebab daya saing UMKM rendah. Ada beberapa faktor yang dapat mempengaruhi dari daya saing UMKM menurut Annisa dalam penelitiannya yang berjudul Analisis faktor-faktor yang mempengaruhi daya saing UKM di Kabupaten Bantul, yaitu, dari segi sumber daya manusia, keunggulan produk, inovasi, serta pemasaran dengan teknologi informasi (2019). Adanya persaingan tentu membuat usaha mikro, kecil dan menengah harus mempersiapkan modal yang akan dijadikan peran penting dalam memperbaiki kelemahankelemahan yang ada di perusahaan. Modal ini tidak hanya berupa jumlah uang yang dibutuhkan tetapi juga kesiapan pelaku usaha dalam menghadapi situasi dan kondisi pasar yang fluktuatif yang dinamakan dengan modal keahlian. Dengan modal, semua usaha mikro, kecil, dan menengah dapat melaksanakan aktivitas produksi dan aktivitas bisnis lainnya. Tanpa modal, usaha mikro, kecil dan menengah tetap dapat berjalan tetapi hanya dapat melaksanakan aktivitasnya yang sangat terbatas. Pelaku usaha juga tidak dapat merebut pasar dengan baik apabila modal yang ada minim. Dari penelitian terdahulu dapat disimpulkan adanya kesiapan modal akan mempengaruhi aktivitas produksi dan aktivitas bisnis lainnya sehingga membuat usaha mikro, kecil, dan menengah secara tidak langsung tidak dapat merebut pasar dengan barang dan jasa yang ditawarkan. Lambat laun UMKM akan mengalami penurunan omzet. Berbagai kegiatan dilakukan untuk memberikan kesiapan modal bagi perkembangan UMKM Kain tenun Palembang, baik di bidang Teknologi maupun di bidang manajemen. Sumber daya manusia manusia pada KUBe Griya kain Tuan Kentang adalah masyarakat disekitar lokasi industri yang dapat menyerap tenaga kerja tetapi kurangnya kemampuan SDM dalam mendesain motif dan kombinasi warna.Khusus di Griya Kain Tuan kentang . SDM pengelola belum 
mempunyai dan memahami kemampuan berbahasa terutama bahasa Inggris praktis sehingga kesulitan memberikan pelayanan kepada pembeli asing,hal ini mengurangi peluang mendapatkan keuntungan.Pelatihan akuntansi dan perpajakan. Sosialisasi Legalitas usaha

\section{METODE PENERAPAN}

Khalayak sasaran kegiatan melibatkan sumber daya manusia yaitu Kube Griya kain Tuan Kentang dengan 24 Unit usaha, pimpinan sekaligus pengrajin usaha tenun dan pengurus Toko atau Showroom KUBe Kain tenun sebanyak 5 orang. Metode pendekatan yang digunakan dilakukan dengan beberapa tahapan sebagai berikut: Dalam rangka mencari tahu permasalahan maka perlu dilakukan inventarisasi.dalam pola ini sudah dilakukan survey pendahuluan ke Lokasi mitra, selanjutnya dilakukan inventarisasi mengenai data-data UMKM yang akan didampingi dan pengelompokan klasifikasi jenis permasalahan yang dihadapi .Setiap kegiatan akan selalu didiskusikan antara ketua pelaksana dan pihak KUBe Griya Kain Tuan Kentang. Pendampingan dilakukan sebagai sarana monitoring dan memandu pengelola UMKM untuk menerapkan teori yang diperoleh, Secara spesifik kegiatan meliputi pengajaran, konsultasi dan bimbingan dalam mengimplementasikan berbahasa Inggris praktis, Pembukuan, Keuangan dan perpajakan. Pendampingan dilakukan dalam bentuk Pelatihan yang diberikan ke UMKM, baik bagi karyawan maupun pengelola KUBe. untuk Pengajaran berbahasa Inggris praktis dilakukan secara rutin selama 3 bulan, dua kali setiap minggunya, mengambil waktu sore hari jam 15.00 , dipilihnya waktu sore hari karena UMKM di pagi harinya memproduksi atau menenun kain dan memasarkanya. Pendampingan di bidang pembukuan, Keuangan dan perpajakan diberikan oleh Narasumber yang mempunyai Kompetensi mengajar dan melatih bidang tersebut, yang juga staf pengajar pada Ikatan Akuntan Indonesia (IAI) Palembang dan juga Ketua Tax Centre Politeknik Negeri Sriwijaya. Selanjutnya sosialisasi pengetahuan legalitas dengan mendatangi narasumber pada Dinas Koperasi dan UMKM SumSel, sedangkan pengurusan legalitas didampingi oleh notaris Mahani, SH.

Pendampingan tahap awal tim pelaksana memfokuskan pada penjelasan tentang materi pelatihan. Pada pendampingan kedua mengevaluasi dan mereview pemahaman dan keterampilan yang sudah dimiliki diadakan tes atau praktek atau simulasi. Selanjutnya akan mengoreksi bilamana ada kesalahan atau kekurang pahaman dalam penerapannya. Pendampingan selanjutnya selain memonitor dan memandu Tim pelaksana mengevaluasi kondisi materi pelatihan dan juga penerapannya dalam pengelolaan usaha oleh UMKM tersebut. Adapun kegiatan keseluruhan akan dipantau dengan melibatkan Ketua Lembaga Penelitian dan Pengabdian Masyarakat Politeknik Negeri Sriwijaya. Untuk mengetahui keberhasilan dari setiap kegiatan yang telah dilaksanakan, maka akan dilakukan penilaian secara bertahap, antara lain kemampuan Berbahasa Inggris praktis. Penilaian ini akan dilaksanakan oleh pihak yang berkompeten yaitu Pengajar dan Pelatih Bahasa Inggris dan juga calon pembeli kain tenun atau Tamu asing yang bertamu dan berbelanja ke KUBE Griya Tuan Kentang Indikator kinerja dilakukan dengan memberikan evaluasi kepada poin-poin: Berbahasa Inggris dalam menyambut tamu, transaksi jual beli, memperkenalkan seputar produk dan produksi kain tenun Palembang. Pelatihan di bidang pembukuan, Akuntansi dan perpajakan, indikator kinerja dilakukan dengan memberi pengajaran teknik pembukuan, sosialisasi pajak, teknis penetapan harga pokok produk, pendampingan penyusunannya sehingga dihasilkan laporan keuangan yang tepat. Pemahaman tentang Legalitas Usaha dilanjutkan dengan pendampingan dalam mengurus legalitas usaha. Selanjutnya dibuat laporan kegiatan. Indikator kinerja dievaluasi melalui seminar tingkat lembaga dengan poin-poin: Format laporan, Substansi serta tata tulis.

Evaluasi pelaksanaan program dilakukan dengan cara memantau dan memonitor kinerja mitra secara berkala sejak program pengabdian akan berjalan. Pendampingan dilakukan sebagai saran monitoring dan memandu pengelola UMKM untuk menerapkan teori yang diperoleh, Secara spesifik kegiatan meliputi konsultasi dan bimbingan dalam berkomunikasi dalam bahasa Inggris serta konsultasi dan bimbingan dalam menyusun Laporan Keuangan, penetapan harga pokok dan perhitungan pajak serta pemahaman tentang Legalitas usaha.Pendampingan dilakukan dalam bentuk kunjungan lapangan ke UMKM untuk memantau secara intensif selama 3 bulan. Pendampingan tahap awal tim pelaksana memfokuskan pada penjelasan tentang materi pelatihan Pada pendampingan kedua mengoreksi bilamana ada kesalahan atau kekurang pahaman dalam penerapannya.Pendampingan ketiga Tim Pelaksana melanjutkan Pendampingan keempat , selain memonitor dan memandu pengelola UMKM menerapkan percakapan Berbahasa Inggris dan Keuangan, Tim pelaksana mengevaluasi kondisi materi pelatihan dan juga penerapannya dalam pengelolaan usaha oleh UMKM tersebut. 


\section{HASIL DAN KETERCAPAIAN SASARAN}

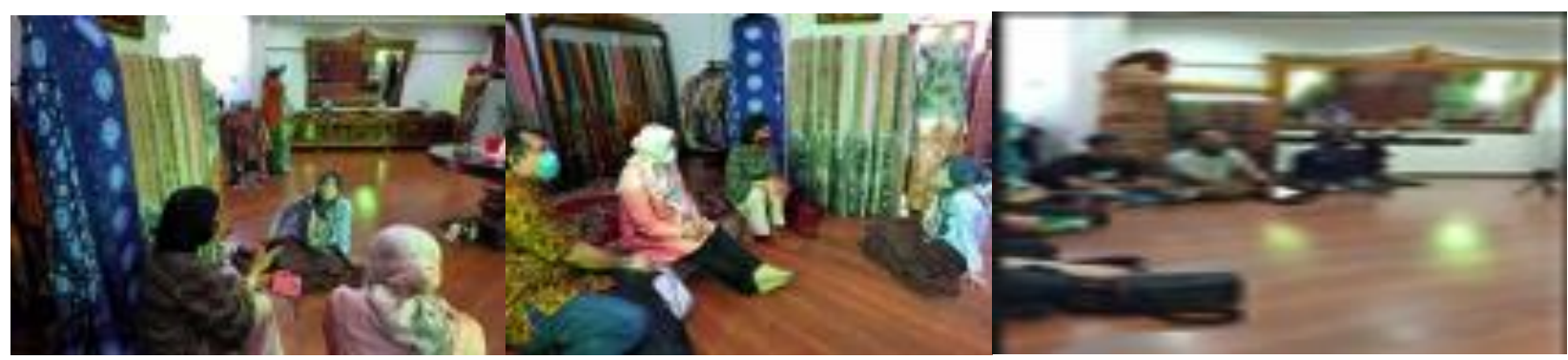

Gambar 2. Sosialisasi dan koordinasi kegiatan oleh Tim dan KUBe

Pada bulan Februari sebelum dunia diserang wabah corona adanya peluang mengembangkan pemasaran produk kain Griya Tuan Kentang dengan kehadiran tamu dari luar negeri Prof. Marlis Brunner dari Senior Experten Services (SES) Jerman yang berkunjung ke Politeknik Negeri Sriwijaya dan berkeinginan mengunjungi salah satu industri kecil di Palembang. Dan juga Tim Bank Indonesia dari Negara Singapura. Dengan kehadiran tamu-tamu asing ini secara tidak langsung turut mengembangkan pemasaran kain tradisional Palembang.



Gambar 3. Kunjungan Tamu Asing dan Tim Pelaksana

Tim pelaksana terdiri dari 4 orang Dosen dan 4 orang mahasiswa, mengagendakan kegiatan bersama dengan KUBe Griya Kain Tuan Kentang pada minggu ke 2 bulan Maret, persiapan untuk implementasi sudah disiapkan, tetapi sewaktu kegiatan akan diimplementasikan wabah corona berjangkit ,termasuk di Indonesia. Pada masa tersebut beragam peraturan diberlakukan Pemerintah. Kondisi ini tidak memungkinkan untuk dilaksanakannya kegiatan.

\section{Pelatihan berbahasa inggris praktis}

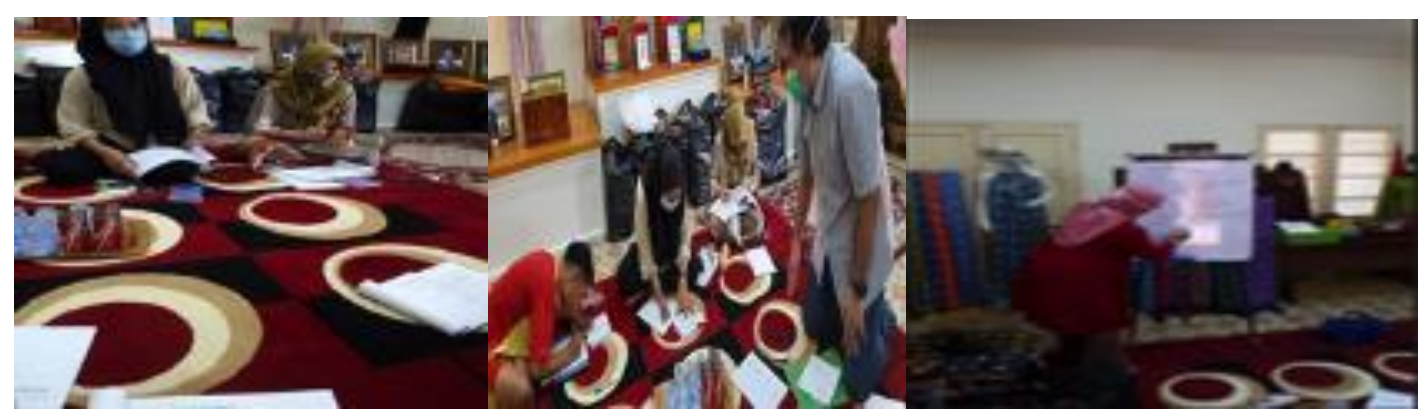

Gambar 4. Pelatihan Bahasa Inggris praktis 


\section{Pelatihan pembukuan, keuangan, perpajakan dan perhitungan harga pokok}
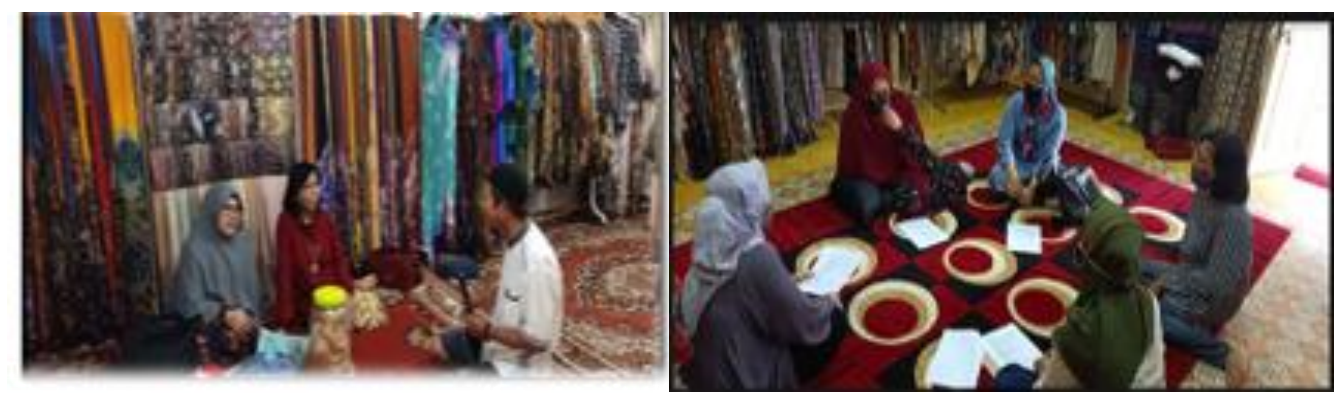

Gambar 5. Sosialisasi kegiatan pembukuan,akuntansi dan perpajakan

3. Sosialisasi legalitas usaha dan pendampingan pembuatan dokumen legalitas usaha.

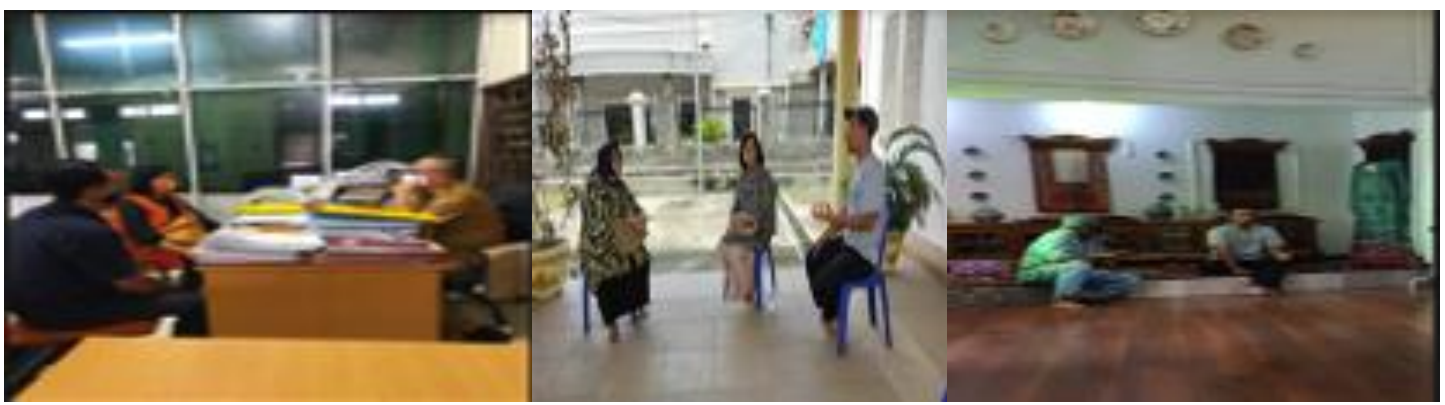

Gambar 6. Sosialisasi Legalitas usaha oleh Departemen Koperasi dan Pendampingan oleh Tim pelaksana dan notaris.

Hasil penerapan Teknologi membawa nilai tambah UMKM tertera pada tabel 1.

Tabel 1. Nilai tambah dari penerapan Kompetensi Kewirausahaan pada UMKM

Teknologi Nilai tambah

Pelatihan Bahasa Inggris praktis

Pelat. Akuntansi dan perpajakan

Sosialisasi Legalitas usaha
Pengetahuan dan keterampilan berbahasa Inggris meningkat sebesar $45 \%$

Pengetahuan dan ketrampilan di bidang akuntansi dan perpajakan meningkat sebesar $45 \%$

Pengetahuan mengenai legalitas usaha meningkat sebesar $30 \%$

Sumber: Hasil Pengolahan data

\section{KESIMPULAN}

Dari hasil pelaksanaan yang telah dilakukan di KUBe Griya Kain Tuan Kentang Palembang, diinventarisasi dan dapat disimpulkan dilaksanakannya kegiatan PPPUD oleh Tim pelaksana berupa Pelatihan berbahasa Inggris praktis, Pelatihan Akuntansi dan Perpajakan dan legalitas usaha dan Pendampingan Legalitas Usaha meningkatkan kompetensi Kewirausahaan Sumber daya manusia pada KUBe Griya Kain Tuan Kentang. 


\section{UCAPAN TERIMA KASIH}

Ucapan terima kasih kepada Dirjen DIKTI / KEMENDIKBUD yang telah mendanai kegiatan pengabdian masyarakat multi tahun selama 3 tahun periode 2019 sampai 2021, dan juga Civitas Politeknik Negeri Sriwijaya yang memberikan dukungan moril dan material hingga pelaksanaan kegiatan PPPUD dapat berjalan dengan baik. Terima kasih kepada UNRI yang memberikan kesempatan mempublikasi artikel hasil kegiatan PPPUD ini.

\section{DAFTAR PUSTAKA}

Badan Standardisasi Nasional. 2013. Sistem Manajemen Mutu SNI ISO 9001:2008, Penerapan pada UKM, oleh Badan Standardisasi Nasional Jakarta.

Bank Indonesia. 2005. Materi Pelatihan Unit Pengembangan Usaha kecil Menengah Untuk Penyusunan Laporan Permohonan Kredit,Proyek Pengembangan Usaha Kecil(SEDP V), Jakarta.

Dipta, W. I. 2012. Memperkuat UKM Menghadapi Masyarakat Ekonomi Asean Tahun 2015. Infokop, 2 1-12.

Kuehl, C. R., \& Lambing. P. 2004. Small Business: Fort Worth. TX; Dryden.

Muzakar, I. 2012. Analisis Kompetensi Kewirausahaan, orientasi Kewirausahaan, dan kinerja Industri Mebel. Benefit, $15(2), 135-149$.

Yulina, B. 2019. Laporan Kegiatan Pelaksanaan Tahun ke 1 PPPUD KUBe Griya Kain Tuan Kentang, PPPM Politeknik Negeri Sriwijaya. Palembang

http://www.antarasumsel.com/berita/302266/omzet-umkm-sumsel-meningkat diunduh tanggal 12 Mei 2018 